\title{
LAS CÁMARAS DE VIDEOVIGILANCIA EN LA EMPRESA COMO MEDIO DE PRUEBA EN EL PROCESO LABORAL ${ }^{1}$
}

\author{
Francisco Andrés Valle Muñoz ${ }^{2}$ \\ Profesor Titular de Derecho del Trabajo y de la Seguridad Social \\ Acreditado a Catedrático de Universidad \\ Universidad Pompeu Fabra, Barcelona
}

\begin{abstract}
Las cámaras de videovigilancia son un instrumento tecnológico del que dispone el empresario para controlar la prestación de trabajo, pero, a su vez, son un medio de prueba para acreditar incumplimientos contractuales del trabajador. En el presente estudio se aborda el valor de las cámaras de videovigilancia como medio de prueba en el proceso laboral analizando tres grandes temas: el primero es el relativo a su licitud; el segundo es su naturaleza jurídica como medio de prueba electrónico; y el tercero está relacionado con la prueba sobre la autenticidad y exactitud de lo reproducido en dichas cámaras.
\end{abstract}

The video surveillance cameras are a technological instrument available to the employer to control the provision of work, but, in turn, they are a means of evidence to prove infringements of the worker. In this study, we analyze the value of video surveillance cameras as a means of evidence in the labor process, studying three main issues: the first one is the legality of this means of evidence. The second issue is its nature as electronic evidence. Finally, the third of them is the proof of the authenticity and integrity of the information contained in the cameras.

Title: The surveillance cameras in the company as a means of evidence in the judicial labor process.

Palabras clave: cámaras de videovigilancia; empresa; medio de prueba; proceso laboral. Key words: surveillance cameras; company; means of evidence; labor process.

IUSLabor 3/2021, ISSN 1699-2938, p. 31-59

DOI. 10.31009/IUSLabor.2021.i03.02

\footnotetext{
${ }^{1}$ El presente estudio ha sido desarrollado en el marco del proyecto de investigación titulado: "Nuevos retos tecnológicos del derecho probatorio" (2021-2024) a cargo del Ministerio de Ciencia e Innovación y con número de referencia: PID2020-115304GB-C21.

${ }^{2}$ Miembro del grupo de investigación consolidado reconocido por la Generalitat de Catalunya: "Social and Business Research Laboratory" (SBRLab). Ref. 2017 SGR 1572.
} 
Fecha envío: 21.9.2021 | Fecha aceptación: 22.10.2021

\section{Sumario}

1. Introducción

2. La licitud de las cámaras de videovigilancia en la empresa como medio de prueba

3. Los efectos de las grabaciones obtenidas ilícitamente en la sanción empresarial al trabajador

4. Las cámaras de videovigilancia como medio de prueba electrónico o digital

5. La prueba sobre la autenticidad y exactitud de lo reproducido en las cámaras de videovigilancia

6. Conclusiones

7. Bibliografía 


\section{Introducción}

Las nuevas tecnologías de la información y de la comunicación se han convertido no solamente en una herramienta de control de la prestación de trabajo sino también en un medio de prueba utilizado por el empresario para demostrar judicialmente incumplimientos contractuales del trabajador ${ }^{3}$. En la mayoría de los casos, los propios dispositivos electrónicos permiten dejar constancia de conductas irregulares de los trabajadores que quedan debidamente registradas y que es posible utilizar en el acto de juicio como medio de prueba, en lo que se ha conocido como prueba electrónica o digital.

Ni la Ley 36/2011, de 10 de octubre, Reguladora de la Jurisdicción Social (LRJS), ni tampoco la Ley 1/2000, de 7 de enero, de Enjuiciamiento Civil (LEC) que es de aplicación supletoria en virtud de lo dispuesto en la Disposición Final Cuarta de la LRJS, ofrecen un concepto de prueba electrónica o digital, habiendo sido ésta definida como aquella información contenida en un dispositivo electrónico a través del cual se adquiere el conocimiento de un hecho controvertido mediante el convencimiento psicológico, o bien como consecuencia de fijar una norma legal este hecho como cierto ${ }^{4}$.

Precisamente uno de estos sistemas de control tecnológico empresarial de la prestación de trabajo es el llevado a cabo mediante cámaras de videovigilancia, cuyo uso viene amparado en el poder de control que el artículo 20.3 del Estatuto de los Trabajadores (ET) otorga al empresario ${ }^{5}$, y cuya instalación puede a su vez estar justificada por razones preventivas o disuasorias de actividades ilícitas de terceros, pero también para verificar el adecuado cumplimiento de la prestación de trabajo.

En esta materia, tres han sido los temas que merecen especial atención desde un punto de vista jurídico procesal: el primero de ellos es el relativo a la licitud de las grabaciones efectuadas mediante cámaras de videovigilancia, cuando las mismas se han obtenido con vulneración de derechos fundamentales del trabajador como son el derecho a la intimidad o el derecho a la protección de datos de carácter personal, así como los efectos que ello conlleva no solo a nivel procesal, sino en la sanción impuesta por el empresario al trabajador; el segundo de ellos está relacionado con la naturaleza jurídica autónoma o no de este medio de prueba y su calificación como prueba electrónica o digital y no como

\footnotetext{
${ }^{3}$ Molina NAVARReTE, Cristóbal, "Control tecnológico del empleador y derecho probatorio: Efectos de la prueba digital lesiva de derechos fundamentales", Temas Laborales. Revista Andaluza de Trabajo y Bienestar Social, $\mathrm{n}^{\circ} 150,2019$, p. 331 y ss.

${ }^{4}$ SANChIS CRESPO, Carolina, "La prueba en soporte electrónico", en AA.VV. Las tecnologías de la información y la comunicación en la Administración de Justicia: análisis sistemático de la Ley 18/2011, de 5 de julio, Ed. Thomson Reuters Aranzadi, Cizur Menor, 2012, p. 713 y ss.

${ }^{5}$ FuENTES SORIANO, Olga, "Vídeos, comunicación electrónica y redes sociales: cuestiones probatorias", Práctica de los Tribunales, $\mathrm{n}^{\circ} 135,2018$, p. 31 y ss.
} 
prueba documental; y el tercero de ellos está relacionado con los medios alternativos de prueba sobre la autenticidad y exactitud de lo reproducido en dichas grabaciones para el caso de ser impugnadas. Todos estos temas, serán objeto de análisis en el presente estudio.

\section{La licitud de las cámaras de videovigilancia en la empresa como medio de prueba}

El artículo 24.2 de la Constitución Española (CE) reconoce el derecho a utilizar los medios de prueba pertinentes en un proceso judicial, para articular la defensa y formar la convicción del juzgador. Pero el ejercicio de ese derecho debe limitarse a la práctica de la prueba lícita, es decir, aquella que no se haya obtenido con vulneración de derechos fundamentales ${ }^{6}$.

Por tal motivo el artículo 11.1 de la Ley Orgánica del Poder Judicial (LOPJ) dispone que: "No surtirán efecto las pruebas obtenidas, directa o indirectamente, violentando los derechos o libertades fundamentales". Y de manera paralela, el artículo 90.2 de la LRJS señala que: "No se admitirán pruebas que tuvieran su origen o que se hubieran obtenido directa o indirectamente, mediante procedimientos que supongan violación de derechos fundamentales o libertades públicas".

Aunque el artículo 11.1 de la LOPJ alude a "derechos o libertades fundamentales", se impone una interpretación estricta de lo que el legislador entiende por "derechos fundamentales" cuya violación genera la ilicitud de la prueba y serían concretamente los contenidos en la Sección $1^{\mathrm{a}}$ del Capítulo II del Título I de la CE. Se trata por tanto de los "derechos fundamentales y libertades públicas" a que alude el artículo 90.1 de la LRJS, con exclusión por tanto de los derechos contenidos en la Sección $2^{a}$, cuya rúbrica es la de: "derechos y deberes de los ciudadanos", ya que, de no ser así, sería difícil justificar la limitación del derecho a la prueba (que también es un derecho fundamental), por otro derecho de un rango constitucional inferior. Quedan por tanto excluidos los derechos constitucionales que no sean derechos fundamentales ${ }^{7}$.

El artículo 90.2 de la LRJS recuerda que la ilicitud de una prueba podrá ser suscitada por cualquiera de las partes o de oficio por el Tribunal en el momento de la proposición de la prueba, salvo que se pusiese de manifiesto durante la práctica de la misma una vez admitida. A tal efecto, se oirá a las partes y, en su caso, se practicarán las diligencias que se puedan llevar a cabo en el acto del juicio sobre este concreto extremo, recurriendo a

\footnotetext{
${ }^{6}$ BLÁZQueZ Agudo, Eva María, Aplicación práctica de la protección de datos en las relaciones laborales, Ed. CISS, Madrid, 2018, p. 240 y ss.

${ }^{7}$ Lousada Arochena, José Fernando, "La prueba ilícita en el proceso laboral", Aranzadi Social, no 5, 2006, p. 835 y ss.; GIL PlanA, Juan, La prueba en el proceso laboral, Ed. Thomson Reuters Aranzadi, Cizur Menor, 2005, p. 202 y ss.
} 
diligencias finales solamente cuando sea estrictamente imprescindible y la cuestión aparezca suficientemente fundada. Contra la resolución que se dicte sobre la pertinencia de la práctica de la prueba y en su caso de la unión a los autos de su resultado o del elemento material que incorpore la misma, sólo cabrá recurso de reposición, que se interpondrá, se dará traslado a las demás partes y se resolverá oralmente en el mismo acto del juicio o comparecencia, quedando a salvo el derecho de las partes a reproducir la impugnación de la prueba ilícita en el recurso que, en su caso, procediera contra la sentencia $^{8}$. Y de manera similar, el artículo 287 de la LEC regula el incidente que ha de seguirse en el proceso civil cuando en la obtención u origen de alguna prueba admitida se han vulnerado derechos fundamentales ${ }^{9}$.

De ambos preceptos se desprende que, si la ilicitud resulta clara, el juzgador debe inadmitir la prueba, sin perjuicio del oportuno recurso de reposición contra la resolución de inadmisión por la parte perjudicada. Pero también es cierto que, si le ofrece dudas, no admitirla podría vulnerar el derecho a la prueba, de ahí la conveniencia de su admisión, sin perjuicio de que la parte perjudicada pueda efectuar la oportuna protesta en el acto de juicio a los efectos del posterior recurso contra la sentencia, una vez ésta hubiera sido dictada ${ }^{10}$.

Esta prohibición de admitir en el seno del proceso pruebas que hayan vulnerado derechos fundamentales, se fundamenta en la posición preferente de éstos en el ordenamiento jurídico $^{11}$. De modo que, admitida la ilicitud de la prueba, la consecuencia será la eliminación de la misma del proceso, no debiendo tenerla en consideración el Juez a ningún efecto ${ }^{12}$.

\footnotetext{
${ }^{8}$ Véase: ARAMENDI SÁNCHEZ, Juan Pablo, "Comentarios al artículo 90 de la LRJS”, en AA.VV. Ley Reguladora de la Jurisdicción Social comentada y con jurisprudencia, Ed. La Ley, Madrid, 2015, p. 648.

${ }^{9}$ Según el artículo 287 de la LEC: "1. Cuando alguna de las partes entendiera que en la obtención u origen de alguna prueba admitida se han vulnerado derechos fundamentales habrá de alegarlo de inmediato, con traslado, en su caso, a las demás partes. Sobre esta cuestión, que también podrá ser suscitada de oficio por el tribunal, se resolverá en el acto del juicio o, si se tratase de juicios verbales, al comienzo de la vista, antes de que dé comienzo la práctica de la prueba. A tal efecto, se oirá a las partes y, en su caso, se practicarán las pruebas pertinentes y útiles que se propongan en el acto sobre el concreto extremo de la referida ilicitud. 2. Contra la resolución a que se refiere el apartado anterior sólo cabrá recurso de reposición, que se interpondrá, sustanciará y resolverá en el mismo acto del juicio o vista, quedando a salvo el derecho de las partes a reproducir la impugnación de la prueba ilícita en la apelación contra la sentencia definitiva".

${ }^{10}$ LOUSADA AROChENA, José Fernando, "La prueba ilícita en el proceso laboral”, ob cit., p. 831.

${ }^{11}$ ALONso OLEA, Manuel, "Admisibilidad en el proceso como prueba de grabaciones de conversación. El secreto de las comunicaciones y la intimidad personal", en AA.VV. Jurisprudencia constitucional sobre trabajo y Seguridad Social, tomo II, Ed. Civitas, Madrid, 1985, p. 215.

${ }^{12}$ En cualquier caso, es importante distinguir entre la prueba ilegal (a la que alude el artículo 283.3 de la LEC), y la prueba ilícita, y es que mientras que la prueba ilegal es aquella que se obtiene sin respetar las
} 
Para que una prueba sea calificada de ilícita, será necesaria la concurrencia de dos requisitos: en primer lugar que se haya vulnerado algún derecho fundamental, sin que sea suficiente que en el control empresarial que está en el origen se pueda haber cometido alguna irregularidad; y en segundo lugar que exista una conexión funcional entre la vulneración del derecho fundamental y el resultado probatorio ${ }^{13}$.

Por otra parte, un análisis de los supuestos de licitud probatoria en el proceso laboral pone de manifiesto dos datos: el primero de ellos es que la prueba ilícita se obtiene en un momento previo al proceso, y como consecuencia del ejercicio del poder empresarial de control de la relación laboral. Y el segundo dato es la desigualdad real existente entre las partes contractuales, circunstancia ésta que hace que los poderes empresariales de control facilitados por las nuevas tecnologías puedan fomentar situaciones de abuso. Desde esta perspectiva se ha afirmado que, aunque la prohibición de la prueba ilícita en el proceso laboral se proponga como una regla de alcance procesal, en realidad se trata de una aplicación más de la vigencia de los derechos fundamentales del trabajador en el seno de la relación de trabajo, que impone tener en cuenta la desigualdad de origen existente entre empresario y el trabajador, desigualdad que ha de reequilibrarse de forma patente en el proceso de trabajo ${ }^{14}$.

Dicho esto, el control empresarial de la prestación de trabajo mediante cámaras de videovigilancia puede afectar a dos derechos fundamentales del trabajador como son el derecho a la intimidad, y el derecho a la protección de datos de carácter personal.

El derecho fundamental a la intimidad, previsto en el artículo 18.1 de la CE, es aquél que protege la dimensión íntima de las personas. Al respecto, la doctrina constitucional ${ }^{15}$ ha afirmado que: "la función del derecho fundamental a la intimidad es la de proteger frente a cualquier invasión que pueda realizarse en aquel ámbito de la vida personal y familiar

leyes vigentes, la prueba ilícita es la que se obtiene vulnerando directa o indirectamente derechos fundamentales. El legislador en ocasiones induce a confusión, pero la prueba ilícita no es la prohibida por la ley, sino la obtenida y practicada con vulneración de derechos fundamentales: PICÓ Y JUNOY, Joan, “Alcance de la prueba ilícita en la LEC”. Justicia. Revista de Derecho Procesal, no 3-4, 2007, p. 124.

13 Munín SÁncheZ, Lara María, "Las nuevas maneras de trabajar y los nuevos medios de prueba”, en AA.VV. Nuevas tecnologías y nuevas maneras de trabajar: Estudios desde el Derecho español y comparado, Ed. Dykinson, Madrid, 2017, p. 341 y ss.

${ }^{14}$ BAYlos GRAU, Antonio, "Medios de prueba y derechos fundamentales. Especial referencia a la tutela de estos derechos”, en AA.VV. La prueba en el proceso laboral, Ed. CGPJ, Madrid, 1998, p. 245; DEL REY GUANTER, Salvador, "Nuevas técnicas probatorias, obtención ilícita de la prueba y derechos fundamentales en el proceso laboral”, Revista Española de Derecho del Trabajo, nº 37, 1989, p. 65 y ss.; GARCÍA-PERROTE ESCARTIN, Ignacio, La prueba en el proceso laboral, Ed. Civitas, Madrid, 1994, p. 139 y ss.

${ }^{15}$ STC no 292/2000, de 30 de noviembre. 
que la persona desea excluir del conocimiento ajeno y de las intromisiones de terceros en contra de su voluntad". Se trata de un derecho que confiere el poder jurídico de imponer a terceros el deber de abstenerse de toda intromisión en la esfera de la persona y la prohibición de hacer uso de lo así conocido.

Y el derecho fundamental a la protección de datos de carácter personal, pese a su estrecha vinculación con el anterior, es un derecho autónomo, con una regulación propia en el artículo 18.4 de la CE. En este punto, la doctrina constitucional ${ }^{16}$ ha insistido en que es un derecho que: "persigue garantizar a la persona un poder de control sobre sus datos personales, sobre su uso y su destino, con el propósito de impedir su tráfico ilícito y lesivo para la dignidad y el derecho del afectado". Se trata de un derecho que confiere un poder de disposición sobre los datos personales y que permite también al individuo saber quién posee esos datos personales y para qué, pudiendo oponerse a esa posesión o uso ${ }^{17}$.

Se trata por tanto de una materia en la que entran en conflicto ciertos derechos fundamentales del trabajador frente al derecho constitucional a la libertad de empresa. Y con carácter general, a la hora de proteger estos derechos fundamentales, los tribunales han intentado hacerlos prevalecer frente a la potestad de control del empresario. De hecho, el control empresarial de la prestación de trabajo mediante cámaras de videovigilancia es una materia que ha sido abordada en profundidad por la jurisprudencia del Tribunal Supremo, del Tribunal Constitucional y del Tribunal Europeo de Derechos Humanos que se han encargado de establecer toda una serie de reglas de actuación.

El Tribunal Supremo ${ }^{18}$ ha señalado, en términos generales, que es válida la utilización empresarial de cámaras de videovigilancia instaladas por razones de seguridad, para controlar también la prestación de trabajo, siempre que el trabajador conozca de su existencia por haberse colocado carteles que indicaban de su presencia, y ello aunque no hubiera sido informado del destino o tratamiento que podía darse a las imágenes grabadas ni que se las podría utilizar también para controlar la actividad laboral. Este tipo de medidas puede venir justificada por razones de seguridad, expresión amplia que incluiría la vigilancia de actos ilícitos de los trabajadores y de terceros y en definitiva de la seguridad del centro o la preservación de la seguridad de las personas y los bienes, quedando al margen otro tipo de incumplimientos de las obligaciones laborales ajenas a

\footnotetext{
${ }^{16}$ STC n' 29/2013, de 11 de febrero.

17 Arrabal Platero, Paloma, "La videovigilancia como prueba en el proceso", Revista General de Derecho Procesal, n 37, 2015, p. 1 y ss.

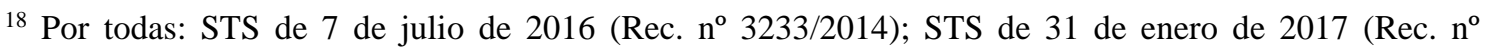

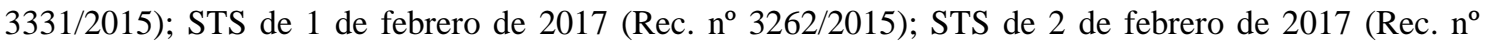
554/2016); y ello, aunque esta falta de información al trabajador pueda suponer una infracción de la normativa sobre protección de datos: STS de 21 de julio de 2021 (Rec. nº 4877/2018).
} 
la seguridad. A juicio del Tribunal Supremo, el requisito que ha de exigirse inexorablemente es que la medida sea razonable y proporcionada al objeto pretendido por el empresario, es decir, que cumpla el juicio de proporcionalidad por ser una medida justificada, idónea, necesaria y equilibrada.

El Tribunal Constitucional ha entendido que se vulnera el derecho a la intimidad del trabajador cuando la empresa no sólo instala cámaras de videovigilancia con las que controlar la prestación de trabajo, sino también micrófonos con los que grabar las conversaciones de los trabajadores y clientes ${ }^{19}$. De igual modo, ha entendido que es lícita la instalación temporal de cámaras ocultas para controlar la prestación de trabajo en un espacio concreto si se tienen sospechas de la comisión de actos ilícitos, sin que ello suponga una intromisión ilegítima en el derecho a la intimidad del trabajador, siempre que se respete el principio de proporcionalidad ${ }^{20}$. También ha insistido en que es necesaria una información previa, expresa, clara, precisa e inequívoca a los trabajadores de la finalidad perseguida con la instalación de cámaras de videovigilancia concretando las características y el alcance del tratamiento de datos que va a realizarse ${ }^{21}$. Pero a la vez, ha precisado que la grabación de imágenes mediante cámaras situadas en un lugar visible y con un dispositivo informativo, no vulneraría el derecho a la protección de datos de carácter personal si se tienen sospechas de la comisión de actos ilícitos por parte de los trabajadores ${ }^{22}$.

Por su parte, el Tribunal Europeo de Derechos Humanos ${ }^{23}$ ha entendido que la instalación temporal por parte de la empresa de cámaras de videovigilancia visibles y otras ocultas, informando a los trabajadores de la existencia de las primeras, pero no de las segundas, no tiene por qué implicar necesariamente una vulneración del derecho a la vida privada del trabajador al tratarse de una medida proporcional y legítima. En tales casos, y cuando exista una sospecha razonable de incumplimiento grave del trabajador, con un indudable perjuicio para la empresa, no sería necesaria la previa información de la instalación de cámaras ocultas al trabajador, y ello porque de informarse previamente, la medida no hubiera servido para el fin pretendido.

Actualmente, y desde un punto de vista estrictamente legal, el artículo 20.3 del ET, establece que: "El empresario podrá adoptar las medidas que estime más oportunas de vigilancia y de control para verificar el cumplimiento por el trabajador de sus

\footnotetext{
${ }^{19} \mathrm{STC}^{\mathrm{o}}$ 98/2000, de 10 de abril.

${ }^{20} \mathrm{STC} \mathrm{n}^{\mathrm{o}} 186 / 2000$, de 10 de julio.

${ }^{21} \mathrm{STC} \mathrm{n}^{\circ} 29 / 2013$, de 11 de febrero.

${ }^{22} \mathrm{STC}^{\circ}$ 39/2016, de 3 de marzo.

${ }^{23}$ STEDH de 17 de octubre de 2019 (asunto López Ribalda II), modificando así la doctrina sentada por la STEDH de 9 de enero de 2018 (asunto López Ribalda y otros contra España).
} 
obligaciones y deberes laborales, guardando en su adopción y aplicación la consideración debida a su dignidad...". Y el artículo 20.bis del ET, con el título: "Derechos de los trabajadores a la intimidad en relación con el entorno digital y a la desconexión", señala que: "Los trabajadores tienen derecho a la intimidad...frente al uso de dispositivos de videovigilancia... en los términos establecidos en la legislación vigente en materia de protección de datos personales y garantía de los derechos digitales"24.

Ello significa que cuando estos derechos fundamentales del trabajador están en juego, tanto la obtención como la aportación de las preceptivas pruebas por parte del empresario en el seno del proceso laboral, deberá ser respetuosa con la normativa reguladora de los mismos, y especialmente con la normativa reguladora de la protección de datos personales contenida en el Reglamento 2016/679 de la Unión Europea, de 27 de abril, sobre protección de las personas físicas en el tratamiento de datos personales y la libre circulación de los mismos (RGPD), y en la Ley Orgánica 3/2018, de 5 de diciembre, de Protección de Datos Personales y garantía de los derechos digitales (LOPD) ${ }^{25}$, norma ésta última, que ha establecido una regulación específica sobre la videovigilancia y grabación de sonidos en el lugar de trabajo en su artículo 89.

Dicho precepto lleva por título: "Derecho a la intimidad frente al uso de dispositivos de videovigilancia y de grabación de sonidos en el lugar de trabajo", y señala que el empresario podrá tratar las imágenes obtenidas a través de sistemas de cámaras o videocámaras para el control de los trabajadores "ex" artículo 20.3 del ET siempre dentro del marco legal y con los límites previstos en él. A tales efectos deberá informar de dicha medida con carácter previo y de forma expresa, clara y concisa a los trabajadores y a sus representantes legales, si bien en el supuesto de que se haya captado la comisión flagrante de un acto ilícito por los trabajadores se entenderá cumplido el deber de informar cuando existiese un dispositivo informativo en lugar suficientemente visible a que alude el

\footnotetext{
${ }^{24}$ Véase sobre el tema: GoÑ SEIN, José Luís, La videovigilancia empresarial y la protección de datos personales, Ed. Civitas, Madrid, 2007; GUDE FERNÁNDEZ, Ana, "La videovigilancia en el ámbito laboral y el derecho a la intimidad", Revista General de Derecho Constitucional, ${ }^{\circ}$ 20, 2015; RodRíGUEZ EsCANCIANO, Susana, "Videovigilancia empresarial: límites a la luz de la Ley Orgánica 3/2018, de 5 de diciembre, de protección de datos personales y garantía de los derechos digitales", Diario La Ley, n ${ }^{\circ} 9328$, 2019; NAVARRO NIETO, Federico, "Las facultades de control a distancia del trabajador: videovigilancia y grabación del sonido", Temas laborales. Revista Andaluza de Trabajo y Bienestar Social, n 150, 2019, p. 71 y ss.

${ }^{25}$ SALAS VELASCO, Ana Cristina, "La utilización de las tecnologías de la comunicación e información (TIC) y sus efectos en la práctica de la prueba en el proceso", en AA.VV. Nuevas Tecnologías y Relaciones Laborales. XXIX Jornadas Catalanas de Derecho Social, Ed. CEJFE, Barcelona, 2019, p. 223 y ss.; LóPEZ Balaguer, Mercedes, Ramos Moragues, Francisco, "Derecho a la intimidad y a la protección de datos y licitud de la prueba en el proceso laboral", en AA.VV. Derecho del Trabajo y nuevas tecnologías, estudios en homenaje al profesor Francisco Pérez de los Cobos Orihuel, Ed. Tirant lo Blanch, Valencia, 2020, p. 387 y ss.
} 
artículo 22.4 de la Ley. Además, no se admitirá la instalación de sistemas de videovigilancia ni de grabación de sonidos en lugares destinados al descanso o esparcimiento de los trabajadores (tales como vestuarios, aseos o comedores), y la utilización de sistemas similares para la grabación de sonidos sólo se admitirá cuando sean evidentes los riesgos para la seguridad de las instalaciones, bienes y personas en el centro de trabajo, y siempre respetando los principios de proporcionalidad y de intervención mínima.

A efectos de verificar la licitud de la prueba obtenida mediante cámaras de videovigilancia en el lugar de trabajo, de este precepto se desprende las siguientes conclusiones:

En primer lugar, que el empresario ha de informar previamente y de forma expresa, clara y concisa a los trabajadores y en su caso a los representantes legales acerca de la instalación de cámaras de videovigilancia, en lo que se ha dado en llamar "cámaras informadas". Esa información deberá concretar las características y el alcance del tratamiento de datos que va a realizarse, es decir, en qué casos las grabaciones pueden ser examinadas, durante cuánto tiempo y con qué propósitos, y más específicamente, si pueden utilizarse para la imposición de sanciones disciplinarias ${ }^{26}$. Ello significa, desde el punto de vista de la licitud de la prueba, que, si el sistema de videovigilancia se utiliza específicamente para controlar la actividad laboral, será necesaria la obligación empresarial de informar al trabajador sobre este extremo, y de no informarse, la prueba obtenida mediante dichos dispositivos de videovigilancia sería ilícita.

En segundo lugar, que en el supuesto de que se haya captado la comisión flagrante de un acto ilícito por parte de los trabajadores, se entenderá cumplido el deber de informar cuando existiese un dispositivo a que alude el artículo 22.4 de dicha Ley (dispositivos que van dirigidos no a controlar la actividad laboral ordinaria, sino la seguridad en la empresa), en lo que ha dado en llamarse "cámaras de identificación no informadas". Es decir, no existirá el deber empresarial de información en los términos antes expresados si se constata la comisión flagrante de un acto ilícito por parte del trabajador mediante un dispositivo informativo colocado en un lugar suficientemente visible en el que se identifique al menos: la existencia del tratamiento, la identidad del responsable y la posibilidad de ejercitar los derechos previstos legalmente "ex" artículo 22.4 de la LOPD.

\footnotetext{
${ }^{26}$ MOLINA NAVARRETE, Cristóbal, "Control tecnológico del empleador y derecho probatorio: Efectos de la prueba digital lesiva de derechos fundamentales", ob cit., p. 337; ARrabal Platero, Paloma, "La videovigilancia como prueba en el proceso", ob cit., p. 15; FUENTES SORIANO, Olga, "Vídeos, comunicación electrónica y redes sociales: cuestiones probatorias", ob cit., p. 11 y ss.
} 
Posiblemente, lo que se quiera evitar con esta previsión es que se invaliden en el proceso laboral unas grabaciones por considerar que fueron obtenidas con vulneración de derechos fundamentales, pero que, sin embargo, se admitan como prueba de cargo en un proceso penal por el que se persigue la comisión de un delito que ha sido grabado.

La cuestión radica en determinar cuándo un trabajador ha cometido un ilícito flagrante, que eximiría al empresario de cualquier deber de información previa, expresa, clara y concisa en caso de que el mismo fuera captado por una cámara de identificación no informada. La jurisprudencia del Tribunal Supremo ${ }^{27}$ ha dejado al margen aquellos incumplimientos de las obligaciones laborales ajenos a la seguridad de la empresa (como son las ausencias del puesto de trabajo, la falta de rendimiento del trabajador, etc.), pero a la vez ha entendido que existen ciertas actividades (como sucede en el ámbito de las empresas de vigilancia y de seguridad) en las que se confunde el objeto de la prestación de servicios del trabajador con la propia seguridad de la empresa, dando validez a la prueba de los incumplimientos así obtenida ${ }^{28}$.

Otra cuestión a dilucidar es si son lícitas las pruebas obtenidas mediante un sistema de videovigilancia utilizado específicamente para controlar la actividad laboral, del que no se ha informado al trabajador, pero que, por casualidad, demuestra la comisión de un acto ilícito. En tales casos deberían también ser perfectamente admisibles y consecuentemente, debieran poder derivarse de las mismas, las sanciones disciplinarias oportunas al trabajador $^{29}$.

Precisamente, un tema no resuelto por la LOPD es el de la licitud del control de la prestación de trabajo mediante cámaras ocultas, y más concretamente si la empresa puede acudir a ellas ante las sospechas de que el trabajador está cometiendo un acto ilícito. En principio, la ley únicamente legitima el control de la prestación laboral en tales casos mediante cámaras identificadas y no informadas, por lo que el control mediante cámaras ocultas no sería posible, al vulnerar el derecho a la intimidad del trabajador. Sin embargo, la Gran Sala del Tribunal Europeo de Derechos Humanos ${ }^{30}$ sí que ha venido a admitir la videovigilancia con cámara oculta siempre que se respeten ciertas condiciones, ya que la información previa al trabajador haría perder la eficacia de su uso.

Y, en tercer lugar, no se admitirá la instalación de sistemas de videovigilancia en lugares destinados al descanso o esparcimiento de los trabajadores. Y por lo que se refiere a la

\footnotetext{
${ }^{27}$ STS de 31 de enero de 2017 (Rec. $n^{\text {o }}$ 3331/2015).

${ }^{28}$ STS de 21 de julio de 2021 (Rec. no 4877/2018).

${ }^{29}$ FUENTES SORIANO, Olga, "Vídeos, comunicación electrónica y redes sociales: cuestiones probatorias", ob cit., p. 11 y ss.

${ }^{30}$ STEDH de 17 de octubre de 2019 (asunto López Ribalda II).
} 
grabación de sonidos, la misma solo será posible si concurren relevantes riesgos para la seguridad de las instalaciones, bienes y personas en el centro de trabajo, y si se respetan los principios de proporcionalidad y de intervención mínima ${ }^{31}$.

Esta limitación de la grabación de sonidos ya había sido recogida por el Tribunal Constitucional $^{32}$, contrario a legitimar su uso si la empresa ya dispone de otros sistemas de seguridad mediante captación de imágenes y porque la captación de conversaciones y de comentarios privados puede llegar a constituir una intromisión ilegítima en el derecho a la intimidad. En cualquier caso, la grabación deberá respetar el conocido principio de proporcionalidad ya apuntado, de modo que sólo será constitucional cuando tal medida sea idónea para conseguir el objetivo propuesto (juicio de idoneidad); cuando sea necesaria por no existir otra medida más moderada para la consecución de tal propósito con igual eficacia (juicio de necesidad); y finalmente cuando sea ponderada o equilibrada, por derivarse de ella más beneficios o ventajas que perjuicios sobre otros bienes o valores en conflicto (juicio de proporcionalidad en sentido estricto) ${ }^{33}$.

En consecuencia, corresponderá al empresario probar que la grabación de sonido responde a una justificación relacionada con la seguridad de la empresa y que el sistema utilizado implica una intromisión lo menos invasiva posible, quedando descartado el uso de sistemas que permitan la audición continuada e indiscriminada de todo tipo de conversaciones. Además, dicho sistema habrá de ser informado tanto a los trabajadores como a sus representantes legales, al exigir la ley las mismas garantías previstas para los supuestos antes descritos ${ }^{34}$.

Por todo lo expuesto, cabe concluir que la licitud de las cámaras de videovigilancia como medio de prueba, dependerá en última instancia del respeto a los límites antes descritos en los términos expresados por el artículo 89 de la LOPD y precisados por la jurisprudencia a la que hemos hecho referencia.

Y cuando sea necesario a los fines del proceso el acceso a documentos o archivos, en cualquier tipo de soporte (incluidas las grabaciones de cámaras de videovigilancia), que pueda afectar a la intimidad personal u otro derecho fundamental, el Juez o Tribunal, siempre que no existan medios de prueba alternativos, podrá autorizar dicha actuación, mediante auto, previa ponderación de los intereses afectados, a través de juicio de

\footnotetext{
${ }^{31}$ LóPez Balaguer, Mercedes, Ramos Moragues, Francisco, "Derecho a la intimidad y a la protección de datos y licitud de la prueba en el proceso laboral", $o b$ cit., p. 400 y ss.

${ }^{32} \mathrm{STC} \mathrm{n}^{\circ}$ 98/2000, de 10 de abril.

${ }^{33}$ ARRABal Platero, Paloma, "La videovigilancia como prueba en el proceso", ob cit., p. 7 y ss.

${ }^{34}$ LóPez Balaguer, Mercedes, Ramos Moragues, Francisco, "Derecho a la intimidad y a la protección de datos y licitud de la prueba en el proceso laboral", ob cit., p. 405 y ss.
} 
proporcionalidad y con el mínimo sacrificio, determinando las condiciones de acceso, garantías de conservación, aportación al proceso, obtención y entrega de copias e intervención de las partes o de sus representantes y expertos en su caso (artículo 90.4 de la LRJS). Si como resultado de las medidas anteriores se obtuvieran datos innecesarios, ajenos a los fines del proceso o que pudieran afectar de manera injustificada o desproporcionada a derechos fundamentales o a libertades públicas, se resolverá lo necesario para preservar y garantizar adecuada y suficientemente los intereses y derechos que pudieran resultar afectados (artículo 90.6 de la LRJS).

\section{Los efectos de las grabaciones obtenidas ilícitamente en la sanción empresarial al trabajador}

A la hora de abordar los efectos que tienen las grabaciones obtenidas ilícitamente en la sanción que el empresario imponga al trabajador, puede adelantarse que existen dos grandes tesis al respecto ${ }^{35}$.

La primera tesis parte de afirmar que la sanción o el despido disciplinario han de calificarse como de nulos. Esta posición, mantenida por un sector de la doctrina científica $^{36}$ por la jurisprudencia ${ }^{37}$, y abundante doctrina judicial ${ }^{38}$ viene a señalar que la nulidad de la prueba irradia sus efectos al despido o a cualquier otra decisión adoptada por el empresario, que debe ser calificada como de nula.

\footnotetext{
${ }^{35}$ Molina NAVARReTe, Cristóbal, "Control tecnológico del empleador y derecho probatorio: Efectos de la prueba digital lesiva de derechos fundamentales", ob cit., p. 343 y ss.; LACALLE MuLS, Alejandra, "El impacto de las redes sociales y de la mensajería instantánea en la fase probatoria laboral", Iuslabor, no 1 , 2018, p. 240 y ss.; LLUCH CORELL, Francisco Javier, "La prueba ilícita y sus efectos sobre la calificación del despido", Revista de Jurisprudencia. El derecho, n 1, 2015, p. 1 y ss.; BLÁZQUEZ AGUdo, Eva María, "Aplicación práctica de la protección de datos en las relaciones laborales, ob cit., p. 240 y ss.; FALGUERA BARÓ, Miguel Ángel, "Nuevas tecnologías y trabajo (y III): perspectiva procesal" Trabajo y Derecho: nueva revista de actualidad y relaciones laborales, $\mathrm{n}^{\circ} 22,2016, \mathrm{p} .35$ y ss.

${ }^{36}$ Colas NeILA, Eusebi, "Nuevas tecnologías, obtención de pruebas y derechos fundamentales: STSJ de Madrid de 31 de enero de 2002 (AS 2002,916)”, Aranzadi Social, no 1, 2002 p. 3189 y ss.; Colas NeILA, Eusebi, YelAmos BAYARRI, Estela, "Prueba digital lícita y calificación del despido: la constatación judicial de la vulneración de derechos fundamentales no puede suponer otra cosa sino la nulidad", en AA.VV. Nuevas Tecnologías y Relaciones Laborales. XXIX Jornadas Catalanas de Derecho Social, Ed. CEJFE, Barcelona, 2019, p. 272 y ss.

${ }^{37}$ STS de 21 de junio de 2012 (Rec. n $^{\circ}$ 2194/2011); STS de 13 de mayo de 2014 (Rec. no 1685/2013).

${ }^{38}$ STSJ de Cantabria de 19 de julio de 2003 (Rec. n 909/2003); STSJ del País Vasco de 12 de septiembre de 2006 (Rec. no 1270/2006); STSJ de Galicia de 3 de marzo de 2008 (Rec. nº 6219/2007); STSJ del País Vasco de 10 de mayo de 2011 (Rec. $n^{\circ}$ 644/2011); STSJ de Madrid de 18 de diciembre de 2014 (Rec. $n^{\circ}$ 761/2014); STSJ del País Vasco de 9 de abril de 2015 (Rec. no 445/2013); STSJ de Asturias de 22 de enero de 2016 (Rec. no 2404/2015); STSJ de Andalucía de 5 de abril de 2017 (Rec. n 277/2017); STSJ de Cataluña de 9 de marzo de 2017 (Rec. n 39/2017); STSJ del País Vasco de 27 de febrero de 2018 (Rec. no 226/2018); STSJ de Cataluña de 4 de junio de 2019 (Rec. nº 969/2019).
} 
Esta tesis se basa en la teoría de los "frutos del árbol envenenado", de modo que no es posible separar la calificación que se dé a una prueba obtenida ilícitamente de la calificación que deba darse al despido o a cualquier otra sanción, ya que la obtención de dicha prueba se realiza precisamente para la consecuencia de un fin específico que es acreditar los hechos con que despedir o sancionar al trabajador. Y si se vulnera un derecho fundamental para obtener la prueba que fundamente los hechos motivadores del despido o la sanción, la consecuencia será la nulidad de ambas decisiones.

Esta solución resulta más lógica con la protección de los derechos fundamentales de los trabajadores $^{39}$, y así se prevé en el artículo 108.2 de la LRJS al señalar que se declarará nulo el despido que tenga como móvil alguna de las causas de discriminación previstas en la Constitución o en la Ley, o que se produzca con violación de derechos fundamentales y libertades públicas del trabajador. También el artículo 115.1.d) de la LRJS recuerda que la sentencia declarará nula la sanción impuesta al trabajador, cuando ésta tenga como móvil alguna de las causas de discriminación prevista en la Constitución y en la ley, o se produzca con violación de derechos fundamentales y libertades públicas del trabajador. De hecho, así lo ha venido a entender el Tribunal Constitucional en su sentencia no 196/2004, de 15 de noviembre, y también en la sentencia no 29/2013, de 11 de febrero.

La segunda tesis ha sido defendida por otro sector de la doctrina científica ${ }^{40}$ y por la doctrina judicial en numerosos pronunciamientos ${ }^{41}$, y entiende que la sanción o el despido

\footnotetext{
${ }^{39}$ LLUCH CORELL, Francisco Javier, "La prueba ilícita y sus efectos sobre la calificación del despido", $o b$ cit., p. 1 y ss.; BlÁZQueZ AGUdo, Eva María, "Aplicación práctica de la protección de datos en las relaciones laborales, ob cit., p. 240 y ss.

${ }^{40}$ Gil Plana, Juan, La prueba en el proceso laboral, ob cit., p. 219; SEMPERE NAVARRo, Antonio Vicente, SAn Martín MazzucConi, Carolina, Nuevas tecnologías y relaciones laborales, Ed. Aranzadi, Cizur Menor, 2002, p. 57 y ss.; ALEGRE NUENo, Manuel, "Los sistemas de geolocalización como medio de prueba en el proceso por despido", Trabajo y Derecho: nueva revista de actualidad y relaciones laborales, $\mathrm{n}^{\circ} 75$, 2021, p. 9 y ss.

${ }^{41}$ STSJ de Cataluña de 5 de septiembre de 2000 (Rec. n 2890/2000); STSJ de Andalucía de 9 de marzo de 2001 (Sentencia n ${ }^{\circ}$ 1050/2001); STSJ de Madrid de 28 de junio de 2005 (Rec. nº 1885/2005); STSJ del País Vasco de 24 de abril de 2007 (Rec. n ${ }^{\circ}$ 514/2007); STSJ de Aragón de 4 de diciembre de 2007 (Rec. ${ }^{\circ}$ 1004/2007); STSJ de Madrid de 5 de noviembre de 2008 (Rec. $n^{\circ}$ 4747/2008); STSJ de Galicia de 6 de noviembre de 2008 (Rec. $n^{\circ}$ 4148/2008); STSJ de Madrid de 17 de julio de 2009 (Rec. $n^{\circ}$ 2831/2009); STSJ de la Comunidad Valenciana de 16 de febrero de 2010 (Rec. n 3259/2009); STSJ de Madrid de 30 de mayo de 2011 (Rec. $n^{\circ}$ 5990/2010); STSJ de Castilla-La Mancha de 10 de junio de 2014 (Rec. $n^{\circ}$ 1162/2013); STSJ de Madrid de 29 de septiembre de 2014 (Rec. no 1993/2013); STSJ de Castilla-La Mancha de 28 de noviembre de 2014 (Rec. no 1040/2014); STSJ de Canarias de 27 de marzo de 2017 (Rec. no 934/2016); STSJ de la Comunidad Valenciana de 21 de marzo de 2017 (Rec. no 3904/2016); STSJ de Castilla-La Mancha de 12 de enero de 2018 (Rec. no 1416/2017); STSJ de Canarias, de 24 de enero de 2020 (Rec. ${ }^{\circ}$ 899/2019); STSJ de Baleares, de 22 de enero de 2020 (Rec. nº 286/2019) y STSJ de Baleares de 12 de junio
} 
impuestos por el empresario al trabajador sobre la base de una conducta acreditada mediante una prueba ilícita obtenida con vulneración de derechos fundamentales, debiera de aparejar a lo sumo la improcedencia de dicho despido, o el carácter injustificado de la sanción. Esta tesis se basa principalmente, en que debe separarse la valoración de la prueba ilícita de la calificación final que deba darse al despido o a la sanción.

O, dicho de otro modo: la ilicitud de la prueba no supone, en sí misma, la nulidad del despido, por lo que procedería aplicar lo dispuesto en el artículo 55.2 y 4 del ET, y en aquellos casos en que no pueda acreditarse por el empresario el incumplimiento alegado en la carta de despido, al basarse en una prueba obtenida con vulneración de derechos fundamentales, el despido debiera de ser calificado como de improcedente. La voluntad del empresario al despedir o sancionar al trabajador, en ningún caso pretende la vulneración de los derechos fundamentales y libertades públicas de este último, sin perjuicio de que en la obtención de la prueba haya habido tal vulneración, que sería ajena al acto sancionador o extintivo ${ }^{42}$. De esta manera, la prueba obtenida con tal vulneración sería ilícita, y no podría tenerse en cuenta en el proceso, pero en ningún caso cabría hablar de despido nulo, de conformidad con lo dispuesto en el artículo 55.4 del ET.

La inadmisión de la prueba obtenida como consecuencia de la vulneración de algún derecho fundamental sólo conllevaría la imposibilidad de utilizar dicho medio de prueba para acreditar los incumplimientos laborales imputados al trabajador, pero no excluiría la posibilidad de examinar la licitud del despido con el resto de los medios de prueba aportados por el empleador al juicio oral, siempre que los mismos no estuvieran "contaminados" por la prueba declarada ilícita. Consecuentemente, si no se acreditan los hechos imputados para justificar el despido por no contar con otra prueba válida, el despido será declarado improcedente; por contra, si se han aportado otros medios de prueba que permitan constatar el incumplimiento del trabajador, el despido podrá ser declarado procedente.

Esta segunda tesis ha sido acogida por el Tribunal Constitucional en su sentencia $\mathrm{n}^{\circ}$ 61/2021, de 15 de marzo, apartándose con ello de su jurisprudencia anterior. El alto Tribunal descarta que la nulidad de una prueba obtenida por el empresario con violación del derecho a la intimidad y al secreto de las comunicaciones de un trabajador, deba llevar aparejada la calificación de nulidad del despido y considera que no es contrario al derecho a la tutela judicial efectiva la interpretación del artículo 55.5 del ET que lleve a calificar

\footnotetext{
de 2020 (Rec. no 378/2020).

42 FOns CARbonell, Margarita Rosa, "Mensajería instantánea y redes sociales, la prueba en el proceso laboral”, en AA.VV. Nuevas Tecnologías y Relaciones Laborales. XXIX Jornadas Catalanas de Derecho Social, Ed. CEJFE, Barcelona, 2019, p. 298 y ss.
} 
el despido como de improcedente, pese a la nulidad de la única prueba en la que se fundamentaba el despido.

Según el Tribunal Constitucional, no se vulneran los derechos fundamentales del trabajador al calificarse el despido como de improcedente en lugar de nulo, pues "no puede proclamarse que entre la calificación del despido y la reconocida lesión extraprocesal de un derecho fundamental pueda afirmarse la existencia de una consecutiva lógica y jurídica". Dicho de otro modo: la pretensión de nulidad del despido no puede tener sustento en una vulneración de los derechos reconocidos en el artículo 18.1 y 3 de la CE. Y la argumentación contraria a trazar una correlación entre la nulidad de la fuente de prueba y la nulidad del despido, no merece ser calificada de arbitraria o de manifiestamente irrazonable, de ahí que quepa descartar que la calificación del despido como improcedente lesione el derecho a la tutela judicial efectiva.

Al margen de cuál sea al posicionamiento a seguir, algunos autores ${ }^{43}$ han insistido en que cuando exista una violación de un derecho fundamental, por haber obtenido el empresario la prueba del incumplimiento contractual de manera ilícita procederá en todo caso una indemnización resarcitoria por los daños causados según lo dispuesto en el artículo 183 de la LRJS, y ello con independencia de la calificación final del despido. Así lo ha entendido la sentencia del Tribunal Constitucional n $n^{\circ}$ 61/2021, de 15 de marzo, al admitir la indemnización resarcitoria en un caso de despido declarado improcedente, en el que la única fuente probatoria se obtuvo con violación de derechos fundamentales. Según el alto Tribunal entender que en estos casos no hay vulneración de derechos fundamentales para denegar la indemnización resarcitoria sería una argumentación incongruente, ilógica y contradictoria.

\section{Las cámaras de videovigilancia como medio de prueba electrónico o digital}

El segundo tema a abordar es el relativo a la forma en que los hechos reflejados en cámaras de videovigilancia han de ser aportados al proceso laboral, tema que entronca con otro no menos importante, que es precisamente el de la naturaleza jurídico-procesal de este medio de prueba.

Según el artículo 90.1 de la LRJS, las partes, previa justificación de la utilidad y pertinencia de las diligencias propuestas, podrán servirse de cuantos medios de prueba se encuentren regulados en la Ley para acreditar los hechos controvertidos o necesitados de prueba, incluidos los procedimientos de reproducción de la palabra, de la imagen y del

\footnotetext{
${ }^{43}$ Molina NAVARReTe, Cristóbal, "Control tecnológico del empleador y derecho probatorio: Efectos de la prueba digital lesiva de derechos fundamentales", $o b$ cit., p. 349 y ss.; ALEGRE NUENO, Manuel, "Los sistemas de geolocalización como medio de prueba en el proceso por despido", ob cit.,, p. 9.
} 
sonido o de archivo y reproducción de datos, que deberán ser aportados por medio de soporte adecuado y poniendo a disposición del órgano jurisdiccional los medios necesarios para su reproducción y posterior constancia en autos.

Los medios de prueba "regulados en la Ley" y admisibles en el proceso laboral son los descritos, con carácter general, en el artículo 299.1 de la supletoria LEC, y concretamente: el interrogatorio de parte, la prueba documental, la prueba pericial, la prueba testifical, y la prueba de reconocimiento judicial. Pero también se admite la aportación de los medios electrónicos antes descritos. Por ello, el artículo 299.2 de la LEC, señala que también se admitirán, conforme a lo dispuesto en esta Ley, los medios de reproducción de la palabra, el sonido y la imagen, así como los instrumentos que permiten archivar y conocer o reproducir palabras, datos, cifras y operaciones matemáticas llevadas a cabo con fines contables o de otra clase, relevantes para el proceso.

Este precepto reconoce a la prueba electrónica como una prueba autónoma e incluye, por un lado, los medios de reproducción de la palabra, el sonido y la imagen, cuya regulación se desarrolla en los artículos 382 y 383 de la LEC con la terminología legal de "instrumentos de filmación, grabación y semejantes". Y, por otro lado, los instrumentos que permiten archivar, conocer o reproducir palabras, datos, cifras y operaciones matemáticas llevadas a cabo con fines contables o de otra clase (los llamados instrumentos y archivos informáticos), cuya regulación se contempla en el artículo 384 de la LEC con la denominación de "instrumentos que permiten archivar, conocer o reproducir datos relevantes para el proceso".

La admisión de esta prueba electrónica requiere además del cumplimiento de los requisitos previstos en el artículo 90.1 de la LRJS, es decir: que se aporte "por medio de soporte adecuado, poniendo a disposición del órgano jurisdiccional los medios necesarios para su reproducción y posterior constancia en autos".

Cuando el medio de prueba consista en la reproducción de las palabras, imágenes o sonidos captados mediante instrumentos de filmación, grabación y otros semejantes, las partes, al proponer la prueba, deberán acompañar, en su caso, transcripción escrita de las palabras contenidas en el soporte de que se trate y que resulten relevantes para el caso (artículo 382.1 de la LEC). Además, se admite que la parte que proponga este medio de prueba pueda aportar los dictámenes y medios de prueba instrumentales que considere convenientes. Y también las otras partes podrán aportar dictámenes y medios de prueba cuando cuestionen la autenticidad y exactitud de lo reproducido (artículo 382.2 de la LEC) ${ }^{44}$.

$44 \mathrm{Si}$ se trata de instrumentos de archivos o reproducción de palabras, datos, cifras y operaciones matemáticas relevantes para el proceso llevadas a cabo con fines contables o de otra clase, serán examinados 
Por último, se levantará la oportuna acta, donde se consignará cuanto sea necesario para la identificación de las filmaciones, grabaciones y reproducciones llevadas a cabo, así como, en su caso, las justificaciones y dictámenes aportados o las pruebas practicadas (artículo 383.1 de la LEC). Y el material que contenga la palabra, la imagen o el sonido reproducidos, se ha de conservar por el Letrado de la Administración de Justicia, de modo que no sufra alteraciones (artículo 383.2 de la LEC) ${ }^{45}$.

La cuestión a resolver es si las cámaras de videovigilancia mantienen su autonomía como medio de prueba electrónico o, en tanto que la información contenida en ellas puede ser aportada al proceso a través de otros medios, la pierde, pasando a compartir la misma naturaleza del medio probatorio utilizado para incorporarla al juicio. Es decir, se ha discutido si la información contenida en las cámaras de videovigilancia ha de ser considerada como una prueba documental o no, sobre todo cuando los hechos contenidos en las mismas (como son las imágenes captadas) se aportan impresos al acto de juicio en soporte papel, o por transcripción escrita de las conversaciones relevantes para el caso (artículo 382.1 de la LEC).

El que las pruebas obtenidas mediante dispositivos de videovigilancia se consideren o no pruebas documentales no es una cuestión intrascendente, ya que afecta directamente a la posibilidad de revisar los hechos declarados probados en la sentencia a través del recurso de suplicación o de casación. Si se consideran pruebas documentales, cabría la revisión de los mismos por esta vía, en caso contrario no, y es que según el artículo 193.b) de la LRJS, el recurso de suplicación solo podrá revisar los hechos declarados probados en la sentencia de instancia " a la vista de las pruebas documentales y periciales practicadas". Y según el artículo 207.d) de la LRJS, el recurso de casación habrá de fundarse en un error en la apreciación de la prueba "basado en documentos que obren en autos" que demuestren la equivocación del juzgador, sin hacer mención ninguno de estos preceptos a la prueba electrónica o de reproducción de palabra, imagen o sonido.

El Tribunal Supremo ${ }^{46}$ ha señalado, en unificación de doctrina, que la prueba por instrumentos de reproducción de la palabra, la imagen o el sonido no tiene la naturaleza de prueba documental (ni siquiera en aquellos casos en los que se haya aportado la

por el tribunal por "los medios que la parte proponente aporte o que el tribunal disponga utilizar y de modo que las demás partes del proceso puedan, con idéntico conocimiento que el tribunal, alegar y proponer lo que a su derecho convenga" (art. 384.1 de la LEC).

${ }^{45} \mathrm{Si}$ se trata de instrumentos de archivo de datos, la documentación se hará del modo más apropiado a la naturaleza del instrumento, bajo la fe del Letrado de la Administración de Justicia, que adoptará las medidas de custodia que resulten necesarias (art. 384.2 de la LEC).

${ }^{46}$ STS de 16 de junio de 2011 (Rec. no 3983/2010) y STS de 26 de noviembre de 2012 (Rec. n 786/2012). 
transcripción documental de la grabación) y, en consecuencia, no puede utilizarse para revisar los hechos declarados probados en una sentencia por la vía del recurso de suplicación o de casación.

La construcción del Tribunal Supremo descansa sobre dos hilos argumentales: en primer lugar, en la no aplicabilidad del artículo 26 del Código Penal, donde expresamente se reconoce que se considerará documento todo soporte material que exprese o incorpore datos, hechos o narraciones con eficacia probatoria o cualquier otro tipo de relevancia jurídica, a los efectos estrictamente penales. Y, en segundo lugar, en la regulación y el tratamiento separado que la LEC dispensa para este tipo de prueba electrónica respecto de la prueba documental.

Según el Tribunal Supremo, limitándose la ley adjetiva social a establecer en el artículo 90 que se admiten como prueba los medios mecánicos de reproducción de la palabra, de la imagen y del sonido, sin establecer cuál es su naturaleza y qué tratamiento ha de dárseles, habrá que acudir a lo dispuesto en la LEC en este extremo. Y en este sentido, el apartado segundo del artículo 299 de la LEC ha dado un tratamiento autónomo a los medios de reproducción de la palabra, la imagen y el sonido, diferenciándolos así de la prueba documental prevista en el apartado primero. Consecuencia de la consideración de la naturaleza autónoma de tales medios probatorios es el tratamiento diferenciado que reciben en dicha Ley los documentos (artículos 317 a 334) y los medios de reproducción de la palabra, la imagen y el sonido (artículos 382 a 383), por lo que la interpretación del concepto de prueba documental ha de efectuarse de forma restrictiva.

Además, en el proceso laboral, la forma de aportar y practicar una y otra prueba también es diferente, ya que mientras que en la prueba documental ha de darse traslado a las partes en el acto del juicio, la práctica de la prueba de medios de reproducción de la palabra, la imagen y el sonido se realiza en último lugar, una vez que se han practicado todas las pruebas ("ex" artículo 300.1 de la LEC). Y la diferencia entre una y otra prueba no solo se aprecia en la forma de aportación y práctica de la misma, sino en la valoración por el Juez, ya que mientras la prueba documental está sometida a un sistema mixto de valoración probatoria, esta prueba electrónica está sometida al sistema de valoración libre dado que el artículo 382.3 de la LEC insiste en que el Tribunal valorará las reproducciones de la palabra, la imagen o el sonido captadas mediante instrumentos de filmación, grabación u otros semejantes, conforme a las reglas de la sana crítica.

Por todo lo expuesto, debe concluirse que las cámaras de videovigilancia son un medio de prueba electrónico o digital, previsto expresamente en el artículo 90.1 de la LRJS a la hora de referirse a los medios de reproducción de la palabra, de la imagen y del sonido, y 
los hechos declarados probados en la sentencia a través de las mismas, no podrán ser revisados mediante el recurso de suplicación o de casación ${ }^{47}$.

\section{La prueba sobre la autenticidad y exactitud de lo reproducido en las cámaras de videovigilancia}

Una vez aportado el contenido de la cámara de videovigilancia por la parte interesada al proceso, quedaría por analizar tanto su validez como su eficacia probatoria. Y tanto una como otra dependerán de la autenticidad y exactitud de lo reproducido en dichas cámaras $^{48}$. Respecto a la autenticidad, habrá que garantizar el origen de los datos y la fuente de la que proceden. Y respecto a la exactitud habrá que comprobar que el autor aparente de las imágenes grabadas se corresponde con el autor real (para el caso de discutirse la autoría), y habrá que demostrar que la prueba no ha sido manipulada o alterada desde el momento de su extracción o acceso hasta el momento de su aportación al juicio (para el caso de discutirse su integridad).

En esta materia destacan las facultades del Juez o Tribunal a la hora de advertir o alertar a las partes de la conveniencia de aportar otras pruebas que sean coadyuvantes a la hora de acreditar la autenticidad y exactitud de los medios de prueba electrónicos al amparo de lo dispuesto en el artículo 429.1 de la LEC. De ello se desprende que el Juez queda facultado para introducir estas advertencias a las partes, lo cual es especialmente relevante en el proceso laboral, que dota al Juez de importantes facultades en la intervención de la práctica de la prueba, sin que ello ponga en cuestión la imparcialidad del mismo, habida cuenta de las especialidades respecto de los valores y bienes jurídicos tutelados en el proceso social $^{49}$.

Por ello, las partes pueden valerse de los medios de prueba previstos en el artículo 299.1 de la LEC para demostrar la realidad la información contenida en las cámaras de videovigilancia, como son: el interrogatorio de parte, el interrogatorio de testigos, el reconocimiento judicial, los documentos públicos y privados, y el dictamen de peritos.

En base al interrogatorio de parte (artículos 91 de la LRJS y 301 de la LEC), se podría interrogar a la parte contraria (en este caso el trabajador) sobre si tiene conocimiento de

47 Burgos Herrera, Elena, "La utilización del vídeo como sistema de control y medio de prueba", Aranzadi Social, $\mathrm{n}^{\circ} 2,1998$, p. 2660.

${ }^{48}$ SALAS VELASCO, Ana Cristina, "La utilización de las tecnologías de la comunicación e información (TIC) y sus efectos en la práctica de la prueba en el proceso", ob cit.,, p. 221.

${ }^{49}$ GONZÁLEZ GONZÁLEZ, Carlos, "Control empresarial de la actividad laboral mediante la videovigilancia y colisión con los derechos fundamentales del trabajador. Novedades de la Ley Orgánica 3/2018, de 5 de diciembre, de protección de Datos Personales y garantía de los derechos digitales", Revista Aranzadi Doctrinal, $\mathrm{n}^{\circ} 4,2019$, p. 5 y ss. 
la realidad de los hechos constatados mediante las cámaras de videovigilancia de modo que, si se reconoce en los mismos, cabría entender como válida dicha prueba, desplegando plenos efectos. Es decir, la conducta procesal de la parte a la que perjudique la aportación de esta prueba electrónica, consistente en aceptarla, debe ser interpretada como una expresa admisión de la autenticidad y exactitud de la información contenida en ella ${ }^{50}$.

Naturalmente el problema se plantea cuando el trabajador no se reconoce en las imágenes, o entiende que las mismas pueden haber sido manipuladas, cuestionando dicha prueba e impugnándola. En este punto, una cuestión relevante es la relativa a si el proponente de la prueba (el empresario) tiene también la carga de probar la autenticidad y exactitud de la misma o si, por el contrario, ésta carga le corresponde al trabajador impugnante.

Y al respecto ya puede afirmarse que, por aplicación de las reglas sobre distribución de la carga de la prueba, previstas en el artículo 217 de la LEC, la impugnación de esta prueba electrónica va a suponer, automáticamente, un desplazamiento de la carga de probar la autenticidad y exactitud de lo reproducido hacia la parte que la presentó. Siendo ello así, y como esta actitud procesal impugnatoria se acaba convirtiendo en una tónica general en el marco de una estrategia defensiva, se ha apuntado la conveniencia de que los tribunales exigiesen a la parte impugnante una cierta justificación o fundamentación de dicha impugnación, esgrimiendo argumentos razonados y serios y no meramente espurios $^{51}$.

Por lo que se refiere a la prueba testifical (artículos 92 de la LRJS y 360 de la LEC), en el proceso podrán intervenir como testigos aquellas personas conocedoras de los hechos controvertidos relativos al objeto del juicio y más específicamente sobre el contenido de las grabaciones ${ }^{52}$. Los testigos (pensemos por ejemplo en los clientes o en compañeros del trabajador) pueden en este punto dotar de credibilidad a la información incorporada al proceso mediante las cámaras de videovigilancia.

Sin embargo, la doctrina científica ${ }^{53}$ ha señalado que para que la prueba electrónica sea aceptada con mayores garantías, será necesario que la misma sea certificada mediante

\footnotetext{
${ }^{50}$ Colas Neila, Eusebi, Yelamos BAyarRi, Estela, "El WhatsApp como prueba de hechos discutidos en el proceso laboral. ¿Más exigencias que una prueba tradicional?", Revista Internacional y Comparada de Relaciones Laborales y Derecho del Empleo, Vol. 8, nº 2, 2020, p. 48.

${ }^{51}$ FUENTES SORIANO, Olga, "Vídeos, comunicación electrónica y redes sociales: cuestiones probatorias", ob cit., p. 11 y ss.

${ }^{52}$ STSJ de Canarias de 27 de julio de 2016 (Rec. $\mathrm{n}^{\circ}$ 385/2016).

${ }^{53}$ LACALLE MULS, Alejandra, "El impacto de las redes sociales y de la mensajería instantánea en la fase probatoria laboral", ob cit., p. 246; FONS CARBONELL, Margarita Rosa, "Mensajería instantánea y redes sociales, la prueba en el proceso laboral", ob cit., p. 287; Selma Penalva, Alejandra, "La información reflejada en las redes sociales y su valor como prueba en el proceso laboral. Análisis de los últimos criterios
} 
otras vías como son: el reconocimiento judicial; el acta de diligencia de constancia; el acta notarial; y la prueba pericial. Todas ellas exigen la intervención de sujetos profesionales especializados, y van dirigidas a legitimar el contenido de la información contenida en la videocámara ante el Juzgado.

La prueba de reconocimiento judicial (artículo 353 de la LEC), está prevista para el esclarecimiento o apreciación de los hechos debatidos mediante el examen directo por parte del Juez o Tribunal de algún objeto, lugar o persona, por lo que resulta un medio probatorio adecuado para incorporar al juicio la prueba digital. El Juez puede visualizar por sí mismo la grabación de la cámara de videovigilancia, lo cual puede acordarse de forma autónoma o conjuntamente con otro medio probatorio, pero en ningún caso podrá verificar la autenticidad o exactitud de la información contenida en ella, para el caso de que fuese impugnada.

Otra opción sería solicitar al Letrado de la Administración de Justicia que levante acta del contenido de las grabaciones mediante diligencia de constancia "ex" artículo 383 de la LEC. Dicho precepto, con el título: "Acta de la reproducción y custodia de los correspondientes materiales" señala que en la misma debe consignarse cuanto sea necesario para la identificación de las filmaciones, grabaciones y reproducciones llevadas a cabo, así como en su caso, las justificaciones y dictámenes aportados o las pruebas practicadas de modo que no sufran alteraciones. Y precisamente, por la condición de depositario de la fe pública judicial de este interviniente, debería darse el valor probatorio de documento público a estas diligencias de constancia ${ }^{54}$. Ahora bien, al igual que sucedía con el reconocimiento judicial, el Letrado de la Administración de Justicia nada puede decir sobre la autenticidad y exactitud de las imágenes o sobre su posible manipulación.

Por tal motivo, otro de los medios probatorios a los que acudir sería el levantamiento de acta notarial. El Notario, como fedatario público, hará constar mediante un acta de protocolización (documento público), la existencia de la información contenida en dichas grabaciones, las fechas de las mismas, así como las identidades de los intervinientes.

Respecto al contenido del acta notarial cabe precisar lo siguiente ${ }^{55}$ : a) El requerimiento de la actuación notarial solamente podrá hacerlo quien tenga interés legítimo en ello, y

jurisprudenciales", Revista General de Derecho del Trabajo y de la Seguridad Social, n 39, 2014, p. 371; FALGUERA BARÓ, Miguel Ángel, "Nuevas tecnologías y trabajo (y III): perspectiva procesal", $o b$ cit., p. 10; FUENTES SORIANO, Olga, "Vídeos, comunicación electrónica y redes sociales: cuestiones probatorias", ob cit., p. 11.

${ }^{54}$ Colas NeIla, Eusebi, Yelamos BAYARRI, Estela, "El WhatsApp como prueba de hechos discutidos en el proceso laboral. ¿Más exigencias que una prueba tradicional?”, ob cit., p. 52.

${ }^{55}$ Colas NeIla, Eusebi, Yelamos BAYARRI, Estela, "El WhatsApp como prueba de hechos discutidos en el proceso laboral. ¿Más exigencias que una prueba tradicional?”, ob cit., p. 55. 
así, el requirente deberá explicar la razón por la que se desea hacer constar ante Notario las grabaciones de imágenes o de sonido; b) El Notario debe informar al requirente de que la existencia de una copia notarial no supone el permiso para una publicidad indiscriminada de su contenido, correspondiendo al requirente la responsabilidad de no divulgar indebidamente datos personales; c) El Notario debe hacer una serie de comprobaciones técnicas para verificar que el dispositivo pertenece al requirente; y d) Será necesario incluir en el acta todo lo necesario para que se comprenda bien el contenido de las imágenes o de los sonidos grabados.

Ahora bien, la actuación del Notario tampoco puede garantizar que la grabación no haya sido manipulada, de ahí que sea conveniente que en el acta notarial el requirente declare expresamente que no se ha manipulado su contenido, advirtiéndole el Notario de las responsabilidades que asume en caso contrario. Por todo lo expuesto, y ante las dificultades de detectar la manipulación, es recomendable acudir a una prueba pericial (artículos 93 de la LRJS y 335 de la LEC).

La prueba pericial informática permite resolver las carencias del acta notarial, al dar certeza tanto de la autenticidad como de la exactitud de la grabación, certificando el perito la inexistencia de alteración de la misma, y garantizado así la ausencia de manipulación ${ }^{56}$. Por tal motivo, el perito informático resulta indispensable para dar garantías a esta prueba digital, al disponer de los conocimientos especializados sobre la materia, conocimientos que puede aportar ante el Juez mediante el oportuno dictamen. Además, la prueba pericial no solo resulta la más garantista y segura, sino que los hechos declarados probados en la sentencia de instancia a través de la misma, serían revisables a través del recurso de suplicación según dispone el artículo 193.b) de la LRJS ${ }^{57}$.

De hecho, el artículo 382.2 de la LEC, al regular la prueba de filmación y grabación, reconoce precisamente al proponente la posibilidad de aportar "los dictámenes y medios de prueba instrumentales que considere convenientes", y en términos similares reconoce idéntica posibilidad a las otras partes "cuando cuestionen la autenticidad y exactitud de lo reproducido".

En la investigación pericial se distinguen tres fases: la primera es el análisis preliminar para la identificación de la prueba electrónica que se desea obtener; la segunda es la adquisición de los datos electrónicos, conservando las copias y la constatación de las técnicas empleadas para garantizar la integridad de la información; y la última fase es la del análisis forense de la información digital, a cuyo efecto es conveniente que el perito

\footnotetext{
${ }^{56}$ STSJ de Galicia de 23 de febrero de 2012 (Rec. no 4927/2011).

${ }^{57}$ LACALLE MULS, Alejandra, "El impacto de las redes sociales y de la mensajería instantánea en la fase probatoria laboral", ob cit., p. 250.
} 
tenga un mínimo conocimiento de la normativa legal ${ }^{58}$. En cualquier caso, será necesario que el informe pericial sea ratificado en juicio por parte del perito que lo ha elaborado, al exigirlo así el artículo 93.1 de la LRJS, al disponer que la práctica de la prueba pericial se lleve a cabo en el acto de juicio presentando los peritos su informe y ratificándolo.

Ahora bien, aunque la prueba pericial sea la mejor vía para poder llegar a conocer la autenticidad y exactitud de la grabación, también es cierto que es una prueba altamente compleja, que, para practicarse con todas las garantías, resulta lenta y $\operatorname{costosa}^{59}$.

Sea como fuere, cuando no se pudiera deducir la autenticidad y exactitud de lo reproducido en la cámara de videovigilancia, el órgano jurisdiccional valorará la validez y eficacia probatoria de dicha reproducción de acuerdo con el conjunto de las restantes pruebas que han sido practicadas, y conforme a las reglas de la sana crítica "ex" artículos 97.2 de la LRJS y 382.3 de la LEC $^{60}$.

\section{Conclusiones}

I. El uso de cámaras de videovigilancia en la empresa ha tenido una repercusión inmediata en el ámbito de las relaciones de trabajo, al convertirse en un medio de prueba con el que el empresario ha pretendido justificar en el proceso laboral, la imposición de determinadas sanciones disciplinarias ante incumplimientos contractuales del trabajador. Sin embargo, la información recogida por el empresario a través de cámaras de videovigilancia también puede vulnerar ciertos derechos fundamentales del trabajador, como son el derecho a la intimidad, o el derecho a la protección de datos de carácter personal. Para que este tipo de prueba sea admisible en el proceso laboral, será necesario que el empresario no vulnere ningún derecho fundamental en su obtención ya que, en caso contrario, la prueba sería ilícita.

II. A la hora de analizar la licitud o no de esta prueba, y en consecuencia, a la hora de abordar la posible vulneración de algún derecho fundamental del trabajador, el punto de referencia lo constituye actualmente el artículo 89 de la LOPD, que con el título: "Derecho a la intimidad frente al uso de dispositivos de videovigilancia y de grabación de sonidos en el lugar de trabajo", recuerda que el empresario podrá tratar las imágenes obtenidas a través de sistemas de cámaras o videocámaras para el control de los

\footnotetext{
${ }^{58}$ COLAS NeILA, Eusebi, Yelamos BAYARRI, Estela, "El WhatsApp como prueba de hechos discutidos en el proceso laboral. ¿Más exigencias que una prueba tradicional?", ob cit., p. 55.

${ }^{59}$ FUENTES SORIANO, Olga, "Vídeos, comunicación electrónica y redes sociales: cuestiones probatorias", ob cit., p. 11 y ss.

${ }^{60}$ SALAS VELASCO, Ana Cristina, "La utilización de las tecnologías de la comunicación e información (TIC) y sus efectos en la práctica de la prueba en el proceso", ob cit., p. 229.
} 
trabajadores "ex" artículo 20.3 del ET siempre dentro del marco legal y con los límites previstos en él. A tales efectos deberá informar de dicha medida con carácter previo y de forma expresa, clara y concisa a los trabajadores y a sus representantes legales, si bien en el supuesto de que se haya captado la comisión flagrante de un acto ilícito por los trabajadores se entenderá cumplido el deber de informar cuando existiese un dispositivo informativo en lugar suficientemente visible a que alude el artículo 22.4 de dicha Ley. Además, no se admitirá la instalación de sistemas de videovigilancia ni de grabación de sonidos en lugares destinados al descanso o esparcimiento de los trabajadores (tales como vestuarios, aseos o comedores), y la utilización de sistemas similares para la grabación de sonidos sólo se admitirá cuando sean evidentes los riesgos para la seguridad de las instalaciones, bienes y personas en el centro de trabajo, y siempre respetando los principios de proporcionalidad y de intervención mínima.

III. Para abordar los efectos que tiene la prueba obtenida ilícitamente en la sanción o en el despido que el empresario imponga al trabajador, puede adelantarse que existen dos grandes tesis al respecto. La primera tesis parte de afirmar que la sanción o el despido disciplinario impuestos por el empresario han de calificarse como de nulos, ya que la nulidad de la prueba irradia sus efectos al despido o a cualquier otra decisión adoptada por el empresario. La segunda tesis parte de la base de entender que la ilicitud de la prueba no supone, en sí misma, la nulidad del despido o de la sanción, y habrá que estar al resto del material probatorio con el que se pretende demostrar el incumplimiento contractual. Esta segunda tesis parece ser la mayoritaria y ha sido defendida por la reciente jurisprudencia del Tribunal Constitucional.

IV. Aunque la información contenida en las cámaras de videovigilancia pueda aportarse al proceso en soporte papel, insertada en un informe que adjunte las oportunas fotografías impresas, con transcripción escrita de las conversaciones, en realidad estamos ante una prueba electrónica o digital y no ante una prueba documental. Al no ser una prueba documental, mediante la misma no será posible revisar los hechos declarados probados en la sentencia a través del recurso de suplicación o de casación, que solo admiten esta posibilidad a través de pruebas documentales. Al tratarse de una prueba electrónica o digital, la misma deberá ser aportada al acto de juicio por medio de soporte adecuado, poniendo a disposición del órgano jurisdiccional los medios necesarios para su reproducción y posterior constancia en autos.

V. Los principales problemas que plantea la prueba obtenida mediante cámaras de videovigilancia en la empresa están relacionados con la autenticidad y exactitud de su contenido, ya que éste puede ser manipulado. Por ello, en aquellos casos en que la parte no se reconozca autora de los hechos, o impugne la autenticidad y exactitud de dicha 
prueba, resultará necesario acudir a otros medios de prueba alternativos, como son la prueba testifical, y especialmente la prueba pericial informática.

\section{Bibliografía}

Alegre Nueno, Manuel, "Los sistemas de geolocalización como medio de prueba en el proceso por despido", Trabajo y Derecho: nueva revista de actualidad y relaciones laborales, $\mathrm{n}^{\circ}$ 75, 2021.

Alonso OlEA, Manuel, "Admisibilidad en el proceso como prueba de grabaciones de conversación. El secreto de las comunicaciones y la intimidad personal", en AA.VV. Jurisprudencia constitucional sobre trabajo y Seguridad Social, tomo II, Ed. Civitas, Madrid, 1985.

ARAMENDi SÁNCHEZ, Juan Pablo, "Comentarios al artículo 90 de la LRJS", en AA.VV. Ley Reguladora de la Jurisdicción Social comentada y con jurisprudencia, Ed. La Ley, Madrid, 2015.

ARrabal Platero, Paloma, "La videovigilancia como prueba en el proceso", Revista General de Derecho Procesal, n 37, 2015.

BAYlOS GraU, Antonio, "Medios de prueba y derechos fundamentales. Especial referencia a la tutela de estos derechos", en AA.VV. La prueba en el proceso laboral, Ed. CGPJ, Madrid, 1998.

BlázQuez Agudo, Eva María, Aplicación práctica de la protección de datos en las relaciones laborales, Ed. CISS, Madrid, 2018.

Burgos Herrera, Elena, "La utilización del vídeo como sistema de control y medio de prueba", Aranzadi Social, nº 2, 1998.

COlas NeILA, Eusebi, "Nuevas tecnologías, obtención de pruebas y derechos fundamentales: STSJ de Madrid de 31 de enero de 2002 (AS 2002,916)", Aranzadi Social, $\mathrm{n}^{\mathrm{o}} 1,2002$.

Colas NeILA, Eusebi, Yelamos BAYARRI, Estela, "Prueba digital lícita y calificación del despido: la constatación judicial de la vulneración de derechos fundamentales no puede suponer otra cosa sino la nulidad", en AA.VV. Nuevas Tecnologías y Relaciones Laborales. XXIX Jornadas Catalanas de Derecho Social, Ed. CEJFE, Barcelona, 2019. 
ColAS NeILA, Eusebi, YELAMOS BAYARRI, Estela, "El WhatsApp como prueba de hechos discutidos en el proceso laboral. ¿Más exigencias que una prueba tradicional?”, Revista Internacional y Comparada de Relaciones Laborales y Derecho del Empleo, Vol. $8, \mathrm{n}^{\circ} 2,2020$.

DEl REy GuANTER, Salvador, "Nuevas técnicas probatorias, obtención ilícita de la prueba y derechos fundamentales en el proceso laboral", Revista Española de Derecho del Trabajo, nº 37, 1989.

FALGUERA BARÓ, Miguel Ángel, "Nuevas tecnologías y trabajo (y III): perspectiva procesal", Trabajo y Derecho: nueva revista de actualidad y relaciones laborales, $\mathrm{n}^{\circ} 22$, 2016.

Fons CARBOnEll, Margarita Rosa, "Mensajería instantánea y redes sociales, la prueba en el proceso laboral", en AA.VV. Nuevas Tecnologías y Relaciones Laborales. XXIX Jornadas Catalanas de Derecho Social, Ed. CEJFE, Barcelona, 2019.

FUENTES SORIANO, Olga, "Vídeos, comunicación electrónica y redes sociales: cuestiones probatorias”, Práctica de los Tribunales, n 135, 2018.

García-Perrote Escartin, Ignacio, La prueba en el proceso laboral, Ed. Civitas, Madrid, 1994.

GIL PlanA, Juan, La prueba en el proceso laboral, Ed. Thomson Reuters Aranzadi, Cizur Menor, 2005.

GonZÁlez GonzÁlez, Carlos, "Control empresarial de la actividad laboral mediante la videovigilancia y colisión con los derechos fundamentales del trabajador. Novedades de la Ley Orgánica 3/2018, de 5 de diciembre, de protección de Datos Personales y garantía de los derechos digitales", Revista Aranzadi Doctrinal, nº 4, 2019.

GoÑ SEIN, José Luís, La videovigilancia empresarial y la protección de datos personales, Ed. Civitas, Madrid, 2007.

GudE FERnÁnDEZ, Ana, "La videovigilancia en el ámbito laboral y el derecho a la intimidad”, Revista General de Derecho Constitucional, n 20, 2015.

LACALLE Muls, Alejandra, "El impacto de las redes sociales y de la mensajería instantánea en la fase probatoria laboral”, Iuslabor, nº 1, 2018. 
LóPez Balaguer, Mercedes, Ramos Moragues, Francisco, "Derecho a la intimidad y a la protección de datos y licitud de la prueba en el proceso laboral", en AA.VV. Derecho del Trabajo y nuevas tecnologías, estudios en homenaje al profesor Francisco Pérez de los Cobos Orihuel, Ed. Tirant lo Blanch, Valencia, 2020.

LousAda ArochenA, José Fernando, "La prueba ilícita en el proceso laboral", Aranzadi Social, $\mathrm{n}^{\mathrm{o}}$ 5, 2006.

LLUCH CORELL, Francisco Javier, "La prueba ilícita y sus efectos sobre la calificación del despido", Revista de Jurisprudencia. El derecho, n 1, 2015.

Molina NAVARRETE, Cristóbal, "Control tecnológico del empleador y derecho probatorio: Efectos de la prueba digital lesiva de derechos fundamentales", Temas Laborales. Revista Andaluza de Trabajo y Bienestar Social, nº 150, 2019.

Munín SÁNCHEZ, Lara María, "Las nuevas maneras de trabajar y los nuevos medios de prueba", en AA.VV. Nuevas tecnologías y nuevas maneras de trabajar: Estudios desde el Derecho español y comparado, Ed. Dykinson, Madrid, 2017.

NAVARro Nieto, Federico, "Las facultades de control a distancia del trabajador: videovigilancia y grabación del sonido", Temas laborales. Revista Andaluza de Trabajo y Bienestar Social, $\mathrm{n}^{\circ}$ 150, 2019.

PICó Y JunOY, Joan, “Alcance de la prueba ilícita en la LEC”, Justicia. Revista de Derecho Procesal, no 3-4, 2007.

RODRÍGUEZ ESCANCIANO, Susana, "Videovigilancia empresarial: límites a la luz de la Ley Orgánica 3/2018, de 5 de diciembre, de protección de datos personales y garantía de los derechos digitales", Diario La Ley, nº 9328, 2019.

Salas Velasco, Ana Cristina, "La utilización de las tecnologías de la comunicación e información (TIC) y sus efectos en la práctica de la prueba en el proceso", en AA.VV. Nuevas Tecnologías y Relaciones Laborales. XXIX Jornadas Catalanas de Derecho Social, Ed. CEJFE, Barcelona, 2019.

SANCHIS CRESPO, Carolina, "La prueba en soporte electrónico", en AA.VV. Las tecnologías de la información y la comunicación en la Administración de Justicia: análisis sistemático de la Ley 18/2011, de 5 de julio, Ed. Thomson Reuters Aranzadi, Navarra, 2012. 
Selma Penalva, Alejandra, "La información reflejada en las redes sociales y su valor como prueba en el proceso laboral. Análisis de los últimos criterios jurisprudenciales", Revista General de Derecho del Trabajo y de la Seguridad Social, $\mathrm{n}^{\circ} 39$.

Sempere Navarro, Antonio Vicente y San Martín Mazzucconi, Carolina, Nuevas tecnologías y relaciones laborales, Ed. Aranzadi, Cizur Menor, 2002. 